\title{
Improving the Efficiency of Extraction of Sugar Cane Mills Using Rollers with Compound Triple Pitch
}

\section{Mohammed helal ${ }^{1}$, Hassan Mustafa ${ }^{2}$, Yasser Abdelrhman ${ }^{3}$, Ibrahim HassabAllah ${ }^{3}$}

\author{
${ }^{1}$ Egyptian Sugar \& Integrated Industries Company, Deshna, Qena, \\ Egypt . \\ ${ }^{2}$ Egyptian Sugar \& Integrated Industries Company, EL Hawamdiyah \\ ,Giza, Egypt . \\ ${ }^{3}$ Mechanical Engineering Department, Faculty of Engineering, Assiut \\ University, Assiut 71516, Egypt
}

\begin{abstract}
Sugar cane mills are the equipment used in extracting sugar solution from sugar cane plant. The effect of the roller pitch has been studied as one of the constituent parts of the mills by modifying the universal pitch to the triple pitch compound and experimenting with extracting different sugar cane weights ( total nine samples ). On both mills , universal and triple compound pitch on the mills rollers under the same conditions and control of the correct setting taking into account with the uniformity of samples and it was recorded the results were positive by increasing the weight of the squeezed sugar cane in the three - pitch compound rollers mills of extracted juice which increasing percentage up to $3.02 \%$ in contrast to the extraction of single pitch rollers mills which was positive only on low weights.
\end{abstract}

Keywords: Sugar Cane Mills; Rollers; Extraction Efficiency; Compound Triple Pitch.

\section{Introduction}

The sugar industry is one of the important food and strategic industries in the Arab Republic of Egypt .Total sugar production in 2019 is 2.5 million tons[1] , and the sugar is extracted by extracting the sugar solution found in sugar cane and sugar beet, processing the solution by chemical methods and industrial processes to obtain the final sugar product. The methods used in extraction vary depending on the type of plant. In sugar beet extraction process is 
done using diffusion devices only after the process of cleaning and cutting beets into slices, in which the theory of osmotic pressure is applied by moving molecules from the highest concentration to the lowest concentrated solution during the passage of the slices layer of the device then used the highest concentration in the industrial process to complete the stages of the sugar industry. In the sugar cane plant, mills are used in the extraction process and the diffusions devices besides the mills can be used to increase the efficiency of the extraction system after the process of cutting and crushing the sugar cane[2].

The more efficient extraction, greater the amount of juice that helps to increase sugar production, so researchers in the field of mills engineering were studied of how to improve the efficiency of extraction of sugar cane mills to achieve that goal.

In this work, a study conducted in Deshna sugar plants during 2019 will be presented, optimizing the pitch of the rollers mills to achieve increasing of extraction efficiency by increasing the amount of natural juice extracted from the sugar cane.

\section{Mills}

The equipment used in the process of the fibre / bagasse sugarcane plant to obtain the necessary sugar solution as raw material for industrial processes to produce sugar [3].

\subsection{Mills components}

Mills consist of the body of which contains 3 rollers ( feed, top and delivery) with trash plate which put between feed and delivery roller to clean the roller grooves and do as a passage for the bagasse. In addition scrappers to clean the roller grooves in both top and delivery rollers, there is cap which contains piston to activate the hydraulic pressure unit with water cooling circuit and central lubrication circuit to cool and lubricate the journal roller bearing. Figs. 1 and 2 illustrate the aggregate of the mill's parts[4] . 


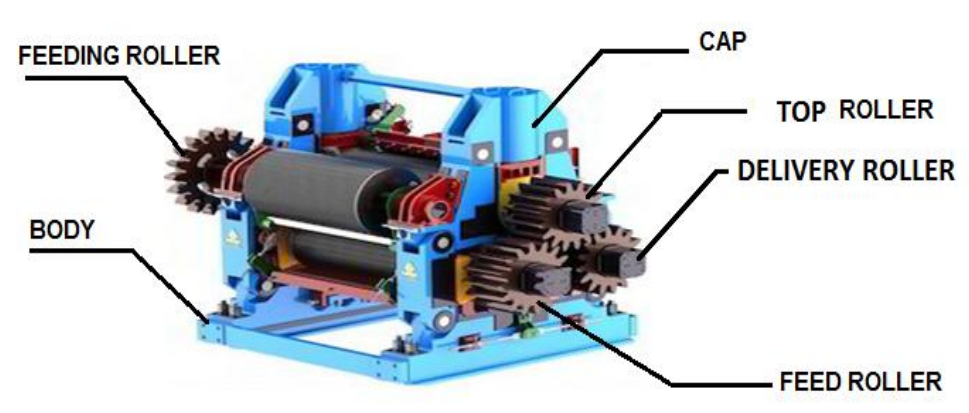

Fig. 1 A photo for an assembled of the mill's parts.

It is noted that good maintenance of all parts of mills and good adjusting the correct setting helps to improve the efficiency of extracting the mills .

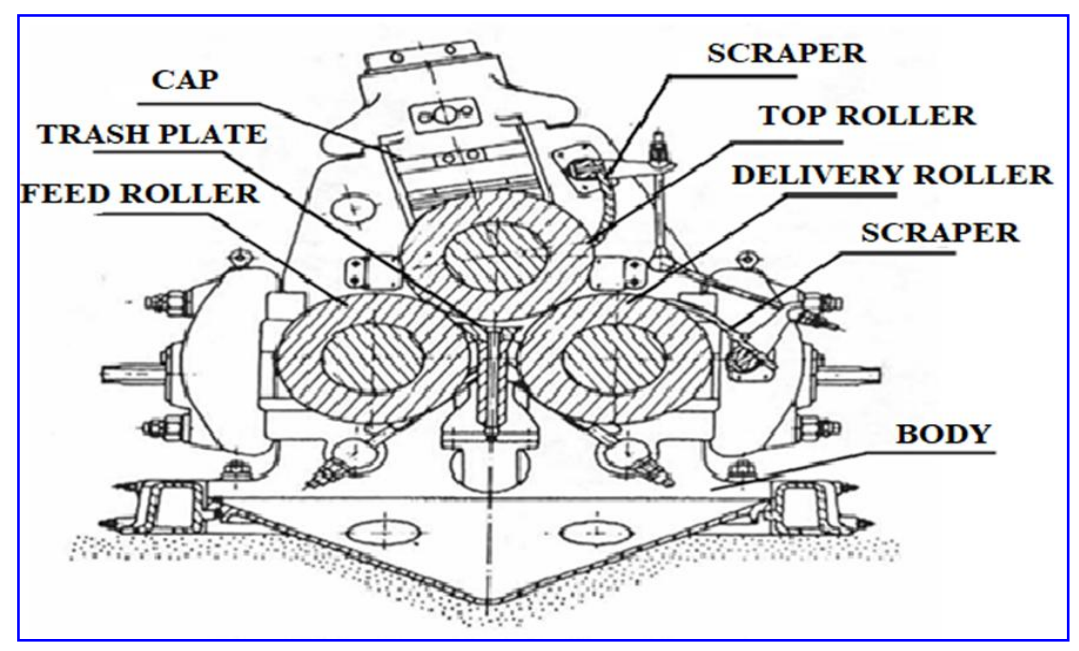

Fig.2 The assembly drawing of the mill parts.

\section{Extraction of the mills}

Extraction is the separation of the sugar solution from the fibre / bagasse of the sugar cane plant. The higher the amount of solution extracted the greater the proportion of extraction and less 
moisture and less sugar losses in the amount of bagasse out of the mills[5].Many factors are affecting on the efficiency of that extraction mill's as the cane preparation which determine the degree of preparation of sugar cane plant after cutting by cutters and shredders , the more the number of cutters used and the number of knives and cutter line increased the amount of juice extracted mills due to increased preparing fibres of sugar cane plants [5]. Hydraulic pressure while greater the value of hydraulic pressure, the greater the ability of the mills to extract so as not to affect the safety of the lower journal bearing of the top rollers [6].

The number of mills in the line and the number of rollers in each mill so more the number of mills in the line and the number of rollers in each mill increased the extraction rate due to the increase in the number of times the compression layers of fibre / bagasse of sugar cane plant. Speed of mills when work at a lower the higher of the extraction rate due to the increase of compression time of the fibre layer / bagasse . Capacity mill's loading for operating the mills at full capacity recommended by the supplier increases the volume and amount of fibre / bagasse passing by the mills, which increases the value of pressure to increase the extraction rate .

Imbibition, which recommended to use the spraying water in the mills to help the mills increase the extraction of the remaining sugar solution on bagasse after the first mills, provided that it does not exceed the recommended amounts so as not to float the bagasse layer, which reduces the extraction rate of the mills [7]. Adjust the correct setting and clearance in mills helps to increase the pressure on the fibre layer / bagasse, which helps to increase the extraction rate.

The technical expertise of workers whereas skilled workers have a role in the diligence of the operation of the mills in the ideal conditions and help to avoid the occurrence of malfunctions and stop the line to obtain the highest efficiency of the mill operation .

Therefore, attention to each of these factors has an effective role in improving the extraction process, and the technical specifications of the rollers of mills contain many details that help when you know that to study the extent of improvement, especially 
the pitch of the rollers in each of the mill rollers. Feed, top and delivery rollers[8] are installed as shown in Figs. 3 and 4.

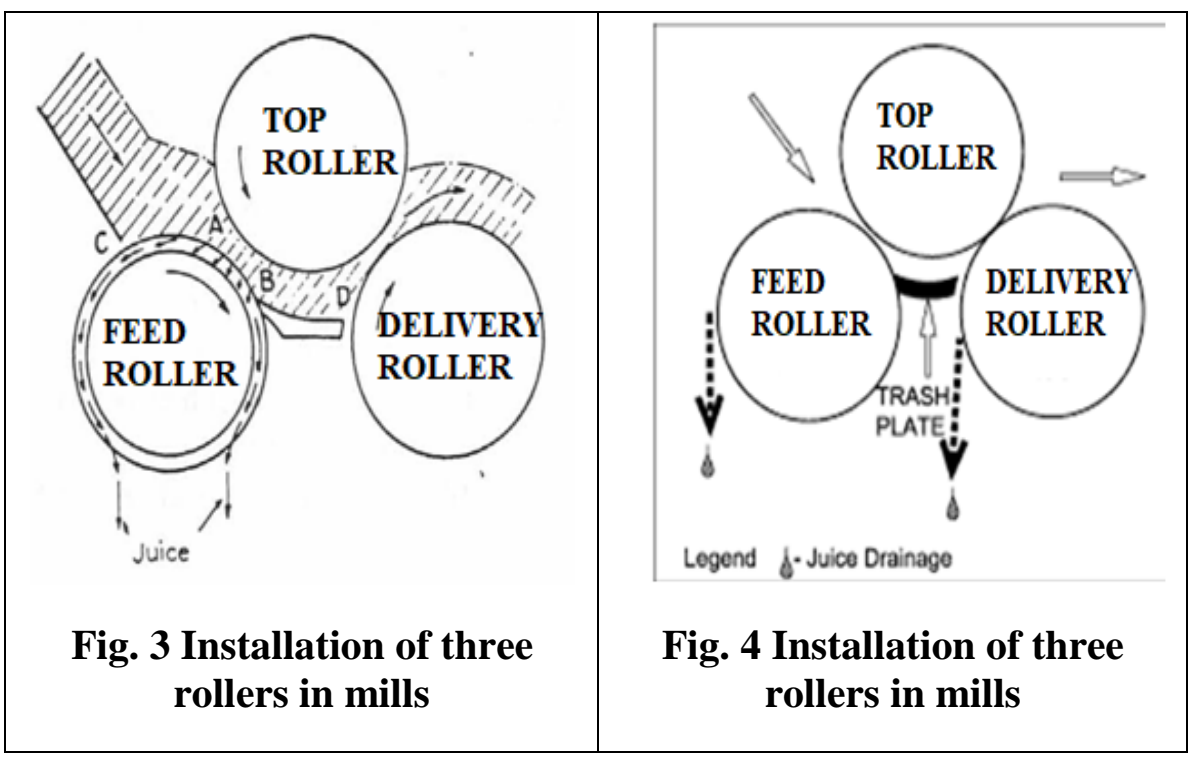

\section{4 - Rollers component}

Fig. 5 shows the components of the full roller as it consists of a steel rod in a cast body with pinion gear for transmission and washers to avoid escaping the bagasse [9].

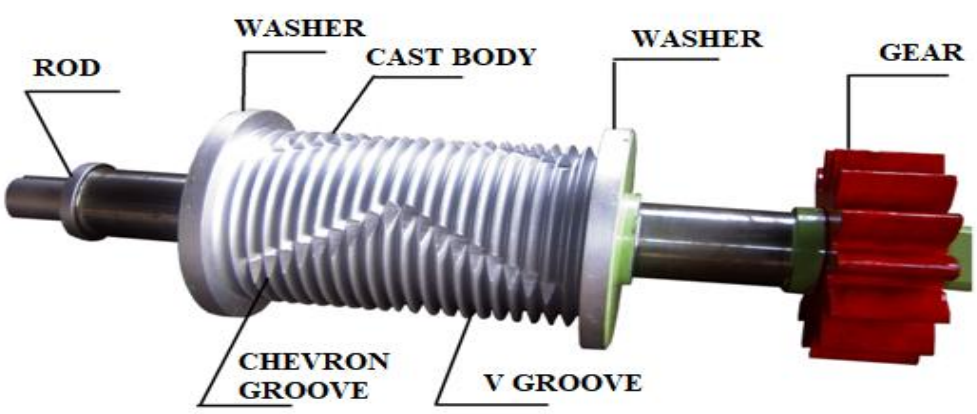

Fig. 5 components of roller 


\subsection{Types of roller grooves}

There are three types of grooves on the rollers [10] :

1 -Vgrooves increase the surface area of rollers and the compression process are done fibre / bagasse to extract the juice and discharge the juice and there are in all the rollers feed, top and delivery as shown in

Fig. 6

2 -Messchaert grooves to increase the discharge of the juice and reduce the loss of juice and there are in the feed and delivery rollers only as shown in Fig. 7

3 -Chevron grooves to increase the withdrawal of the mills and there are in feed rollers only as shown in Figs. 8 and 9

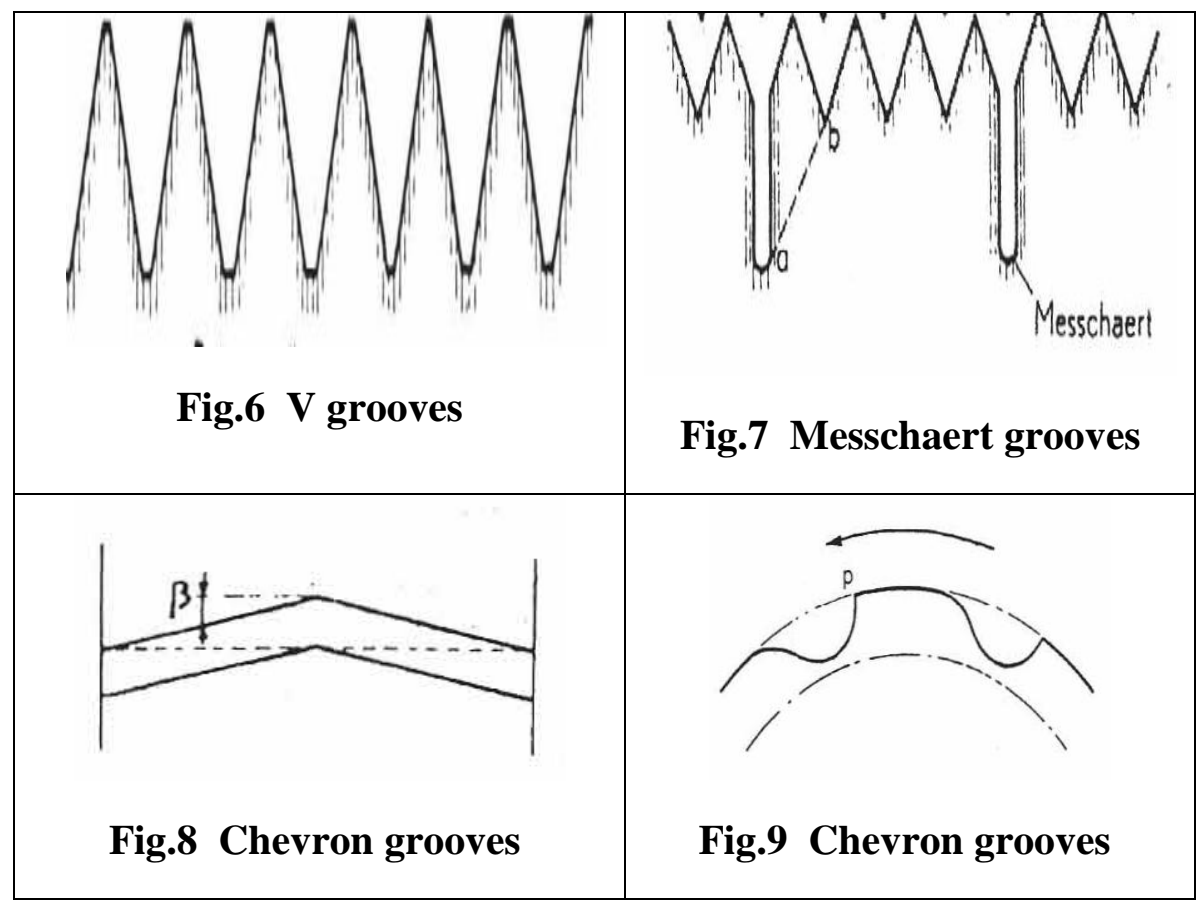




\subsection{Roller pitch}

Is definite as a distance between two consecutive peaks or two consecutive bottoms (TP) as shown in Fig. 10.

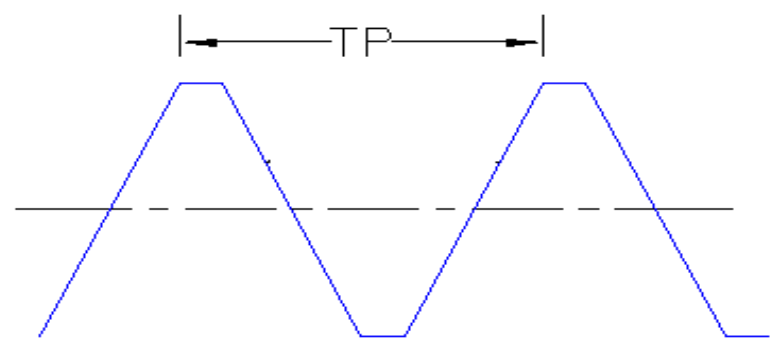

Fig. 10 Roller pitch

The roller pitch is one of the factors that affect on the efficiency of extracting sugar cane mills . But the question here is how to maximize the benefit of the roller pitch to improve the efficiency of the extraction?

In the case of single pitch on the triple roller mills, the extraction process is carried out by passing the fibre / bagasse layer under high hydraulic pressure through 2 openings the first called the feed opening, which is the distance between the mean diameter of the feed and top rollers. The second opening is called the delivery opening, which is the distance between the mean diameter of the delivery and top rollers. However, it was reached to double those openings by adjusting the pitch for each of the rollers of the triple rollers mills by designing rollers with different pitch to achieve good compatibility and overlap between the teeth to be feed roller pitch twice top roller pitch and top roller pitch double delivery roller pitch where the purpose of reducing the pitch of roller during the passage of the fibre / bagasse layer is to reduce the surface area of the compression resulting increasing in pressure helps to increase the extraction. 


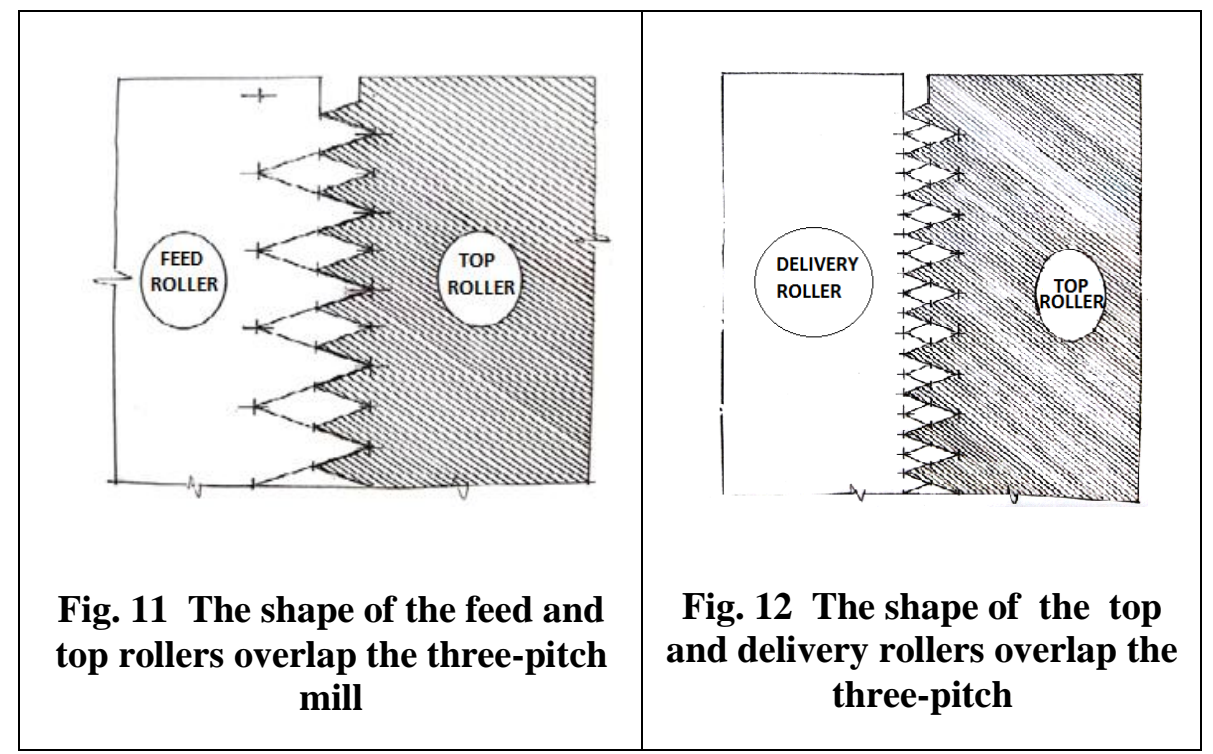

\section{Experimental work, results and discussion}

This theory was applied at one of the lines of Czech mills operating in Deshna sugar factories size $\phi 300 \times 400 \mathrm{~mm}$ by designing a triple mills with a triple composite ( 3 pitch rollers mill's ) and comparing the results of its extract with a triple mills with a uniform pitch ( universal pitch ) at the same operating conditions with the same samples used in both lines of mills. One line consists of 2 mills, the first called sugar cane mill and the second called bagasse mill. Table (1) shows the operating conditions of both mills .

The operating conditions connected to the original supplier of these Czech Skoda mills have been considerate unifying pitch and depth of top rollers in the first mills on the both lines to determine the percentage of increasing the efficiency of extraction in the modified mills and unifying the pitch and depth of the rollers of the feed, the top and the delivery in the second mills on the both lines because of the difficulty of adjusting the setting of the feed / delivery opening. It is working with the first mills and cannot repeat the values of these apertures of the second mills to achieve the effectiveness of extraction along the line as[11] Figs. 11 and 12 show the overlap teeth of pitch on the rollers on the mills . 
Table (1) A statement of the operating conditions of each line uniform and three-pitch mills .

\begin{tabular}{|c|c|c|c|}
\hline $\mathbf{M}$ & STATEMENT & 1 P mills & 3 P mills \\
\hline 1 & Pitch/depth feed roller $1^{\text {st }}$ mill & $9.52 / 8 \mathrm{~mm}$ & $19.04 / 18 \mathrm{~mm}$ \\
\hline 2 & Pitch/depth top roller $1^{\text {st }}$ mill & \multicolumn{2}{|c|}{$9.52 / 8 \mathrm{~mm}$} \\
\hline 3 & Pitch/depth delivery roller $1^{\text {st }}$ mill & $9.52 / 8 \mathrm{~mm}$ & $4.76 / 4 \mathrm{~mm}$ \\
\hline 4 & Inlet/outlet/knife opening $1^{\text {st }}$ mill & \multicolumn{2}{|c|}{$10 / 5 / 20 \mathrm{~mm}$} \\
\hline 5 & Pitch/depth feed roller $2^{\text {nd }}$ mill & \multirow{3}{*}{$9.52 / 8 \mathrm{~mm}$} & \multirow{3}{*}{$9.52 / 8 \mathrm{~mm}$} \\
\hline 6 & Pitch/depth top roller $2^{\text {nd }}$ mill & & \\
\hline 7 & Pitch/depth delivery roller $2^{\text {nd }}$ mill & & \\
\hline 8 & Inlet/outlet/knife opening $2^{\text {nd }}$ mill & \multicolumn{2}{|c|}{ 2/0/14 mm } \\
\hline 9 & Power/speed $1^{\text {st }} \& 2^{\text {nd }}$ mill & \multicolumn{2}{|c|}{18.5 kW / 975 rpm } \\
\hline 10 & reduction ratio $1^{\text {st }} \& 2^{\text {nd }}$ mill & \multicolumn{2}{|c|}{ 250: 1} \\
\hline 11 & Mills speed $1^{\text {st }} \& 2^{\text {nd }}$ mill & \multicolumn{2}{|c|}{$3.9 \mathrm{rpm} / 9.18 \mathrm{~m} / \mathrm{s}$} \\
\hline 12 & Hydraulic pressure $1^{\text {st }} \& 2^{\text {nd }}$ mill & \multicolumn{2}{|c|}{220 bar } \\
\hline
\end{tabular}

It was necessary to consider before starting and when conducting experiments in both lines of mills important points as checking and reviewing the hydraulic pressure circuit, examination and review of the feed and delivery openings mills, check and calibrate the balance device used in the weight of the sugar cane and juice extracted, ensure the integrity and uniformity of the samples used and for good loading of samples when squeezed and extracted so that the samples must be put once and not intermittent quantities .The experiments were carried out on 9 different weights in each line of the mills. The sugar cane, the weight of the pure juice extracted and the extraction ratio of each sample in the threepitch mills line, Table (2) illustrate the weights of the sugar cane samples, the weight of the extracted pure juice and the extraction ratio for each sample in the one pitch mills Line. Table (3) shows the weights of the sugar cane samples, the weight of the pure juice extracted and the extraction ratio for each sample in the three - pitch 
mills line .Table (4) shows the extraction ratio of both lines one and three - pitch mills and the difference between them as the same weight of the pressed sugar cane.

Table (2) Weight of sugar cane and juice extracted and percentage of extraction on the one pitch mills.

\begin{tabular}{|l|c|c|c|}
\hline \multirow{3}{*}{$M$} & \multicolumn{3}{|c|}{ 1P MILLS } \\
\cline { 2 - 4 } & $\begin{array}{c}\text { Net weight of sugar cane } \\
(\mathbf{k g})\end{array}$ & $\begin{array}{c}\text { Net weight of juice } \\
(\mathbf{k g})\end{array}$ & Extraction ratio\% \\
\hline 1 & 20.090 & 12.55 & 62.47 \\
\hline 2 & 20.160 & 12.63 & 62.65 \\
\hline 3 & 20.416 & 12.81 & 62.74 \\
\hline 4 & 25.360 & 16.11 & 63.53 \\
\hline 5 & 25.372 & 16.12 & 63.53 \\
\hline 6 & 25.615 & 16.31 & 63.67 \\
\hline 7 & 30.118 & 19.52 & 64.81 \\
\hline 8 & 30.148 & 19.56 & 64.88 \\
\hline 9 & 30.172 & 19.59 & 64.93 \\
\hline
\end{tabular}

Table (3) Weight of sugar cane and juice extracted and percentage of extraction on the three pitch mills.

\begin{tabular}{|c|c|c|c|}
\hline \multirow{2}{*}{$M$} & \multicolumn{3}{|c|}{ 3P MILLS } \\
\cline { 2 - 4 } & $\begin{array}{c}\text { Net weight of sugar } \\
\text { cane }(\mathbf{k g})\end{array}$ & $\begin{array}{c}\text { Net weight of } \\
\text { juice }(\mathbf{k g})\end{array}$ & $\begin{array}{c}\text { Extraction } \\
\text { ratio\% }\end{array}$ \\
\hline 1 & 20.095 & 12.33 & 61.36 \\
\hline 2 & 20.171 & 12.42 & 61.57 \\
\hline 3 & 20.425 & 12.60 & 61.69 \\
\hline 4 & 25.370 & 16.63 & 65.55 \\
\hline 5 & 25.375 & 16.66 & 65.66 \\
\hline 6 & 25.630 & 16.87 & 65.82 \\
\hline 7 & 30.120 & 20.42 & 67.80 \\
\hline 8 & 30.154 & 20.47 & 67.88 \\
\hline 9 & 30.178 & 20.52 & 68.00 \\
\hline
\end{tabular}


Table (4) Percentage of extraction of both one and three pitch mills and percentage of difference at the Same Weight

\begin{tabular}{|c|c|c|c|}
\hline$M$ & $\begin{array}{c}\text { 1P mills extraction } \\
\text { ratio\% }\end{array}$ & $\begin{array}{c}\text { 3P mills extraction } \\
\text { ratio\% }\end{array}$ & $\begin{array}{c}\text { Difference } \\
\text { extraction ratio\% }\end{array}$ \\
\hline 1 & 62.47 & 61.36 & -1.11 \\
\hline 2 & 62.65 & 61.57 & -1.08 \\
\hline 3 & 62.74 & 61.69 & -1.05 \\
\hline 4 & 63.53 & 65.55 & +2.02 \\
\hline 5 & 63.53 & 65.66 & +2.13 \\
\hline 6 & 63.67 & 65.82 & +2.15 \\
\hline 7 & 64.81 & 67.80 & +2.99 \\
\hline 8 & 64.88 & 67.88 & +3.00 \\
\hline 9 & 64.93 & 68.00 & +3.07 \\
\hline
\end{tabular}

Fig. 13 shows the extraction ratio for both one and three-pitch mills at the same weights, and Fig.14 shows the difference of extraction ratio between both mills ( $1 \mathrm{P} \& 3 \mathrm{P}$ ) at the same weights.

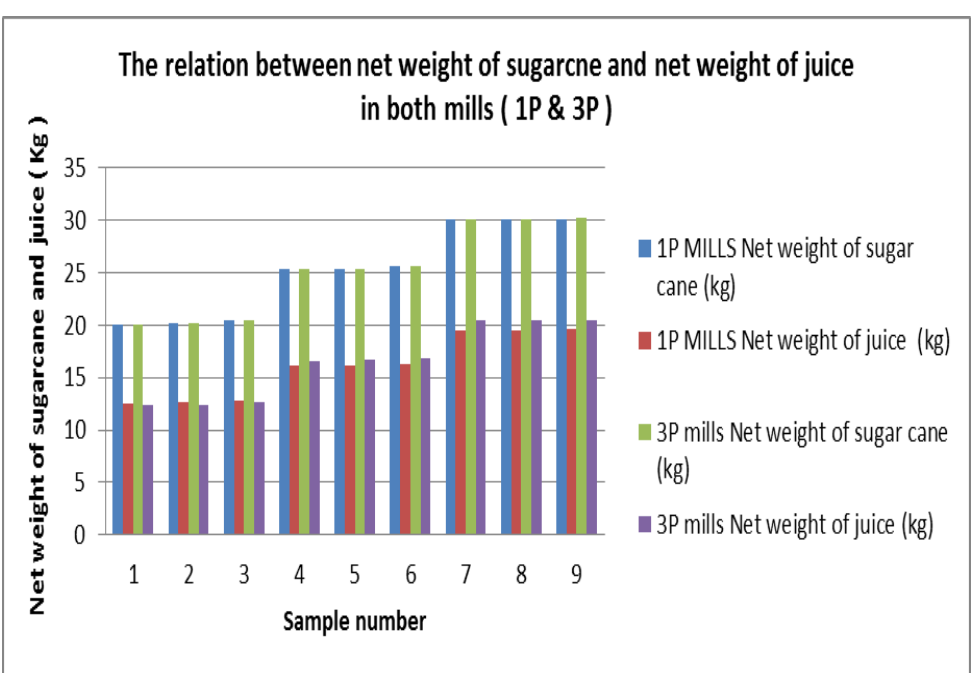

Fig. 13 The extraction ratio for both one and three-pitch mills at the same weights 


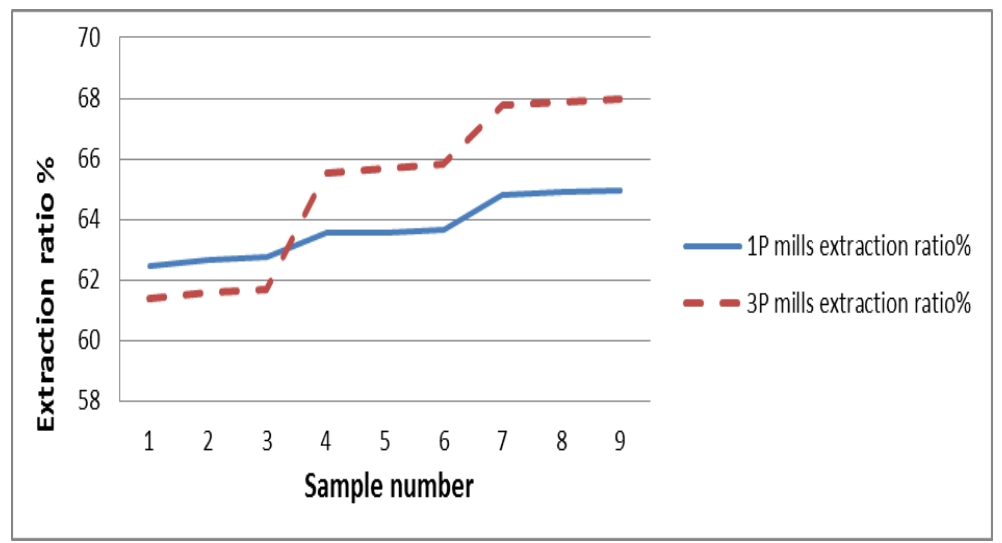

Fig. 14 The difference of extraction ratio between both mills( $1 P \& 3 P)$ at the same weights.

Reducing the roller pitch in the three-pitch rollers mills during the passage of the fibre / bagasse layer led to the reduction of the surface area of the rollers, which increased the pressure generated on the fibre / bagasse layer, which leads to increase the extraction of juice in this layer passing through the feed and delivery mills opening and this helps to increase the juice extracted, which leads to increased sugar production and reduce the amount of juice lost on bagasse after leaving mills and reduce the moisture of the bagasse out of the mills, which helps to reduce the number of fuel used in the burning of the bagasse if used as fuel in steam boilers which generating superheated steam .

\section{Conclusion}

It was concluded that reduced extraction of three-pitch mills from one pitch mills at low weights $( \pm 20 \mathrm{~kg})$ by $\pm 1.08 \%$ and increasing the extraction of three-pitch mills from the one pitch mills whenever the weight of the pressed sugar cane from $( \pm 25 \mathrm{~kg})$ by $\pm 2.1 \%$ to $( \pm 30 \mathrm{~kg})$ by $3.02 \%$.

\section{References}

[1]A. Abdi, A. Counselor, S. R. Omar, A. Specialist, and B. Tate, (2019)."Egypt Sugar Annual Increasing Sugar Supply on Expanded Beet Production," GAIN Rep., vol. EG-19006, pp. 1-9 
[2] J. L. Oliverio, A. C. R. D. Avila, A. N. Faber, and P. A. Soares

(2014).“Juice extraction systems: Mills and diffusers - The Brazilian experience," Int. Sugar J., vol. 116, no. 1383, pp. 190-202,

[3] S. Y. Salunkhe (2015 ). "Static Structural Analysis of Conventional Sugar Mill Roller Shaft for $\varnothing 40$ " 80 " Milling," vol. 5, no. 1, pp. 141-150 .

[4] E. Hugot (1986 ) "Handbook of Cane Sugar Engineering.", Third Edition , Elsever, New York , pp. 348-458

[5] G. E. Monroe, R. L. Nichols, W. L. Bryan, and H. R. Sumner, (1984 ). "Sweet sorghum juice extraction with 3-roll mills," Trans. ASAE, vol. 27, no. 3, pp. 651-654,

[6] C. T. Cosgrove ( 2007 ). "Effects of a Hydraulic Pressure System and Grooved Rollers on an in -Filed Sweet Sorghum Press ," Oklahoma State University

[7] E. Birru et al. (2016). "A Comparison of Various Technological Options for Improving Energy and Water Use Efficiency in a Traditional Sugar Mill”, Sustainability 8, no. 1227 , pp. 1-16,

[8] S. V.V, S. M.C, and P. Patil ( 2015 ) "Weight Reduction and Analysis of Sugar Mill Roller Using FEA Techniques," Inernational J. Latest Trends Eng. Technoloy, vol. 5, no. 1, pp. 346-354.

[9] J. Daniels and C. Daniels, ( 1988 ). "The origin of the sugarcane Roller Mill," Technol. Cult., vol. 29, no. 3, pp. 493-535,

[10] A. Wienese, ( 1995 ). "A milling review," Proc. South African Sugar Technol. Assoc., pp. 192-195,

[11] E.Hugot, ( 1986 ) "Handbook_of_Cane_Sugar_Engineering” , Third Edition, Elsevier , New York, pp. 178-185. 


\section{الالذص العربي}

تصسين كفاءة استخلاص عصارات قصب السكر باستخدام اسهم

\section{ذات خطوة ثلاثية هركبة ( 3 PMILLs )}

همهد هلال احمد ${ }^{1}$ - حسن هصطفى حسن2 - إبراهيم حسب الاله3 - ياسر همهمود عبد الرحمن 3

1 ثنركة السكر والصنا عات التكاملية المصرية - مصانـر سكر دثنا -قنا -

$$
\text { مصر }
$$

2ثنركة السكر والصنا عات التكاملية المصرية - القطا عات الهندسبة -

$$
\text { الهوامدية - الهيزة - مصر }
$$

3 قسم الهندسة الميكانـيكية - كلية الهندسنة - بامعة أسبيوط -أسبيوط -

$$
\text { مصر }
$$

تعتبر عصارات قصب السكر من المعدات المستخدمة في استخلاص المحلول

السكري من نبات قصب السكر. وقد تمت دراسة تأثير خطوة الأسهم كأحد الأجزاء المكونة للعصار ات بتعديل الخطوة الموحدة الى الخطوة الثلاثية المركبة وتجربة ولهية استخلاص تسعة اوزن قصب مختلفة على كلا من خطى عصار ات ذات أسهم موحدة

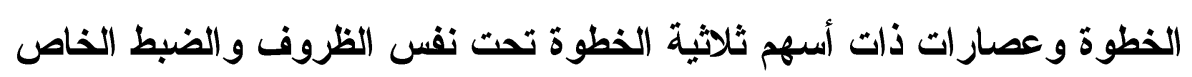
بالعصار ات مع مراعاة تماثل العينات.

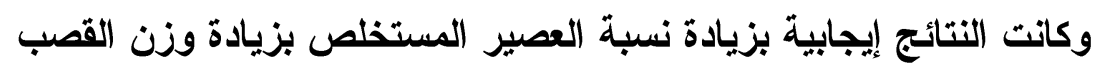

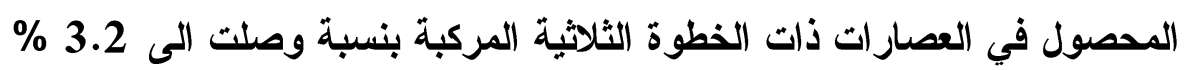
على عكس استخلاص العصار ات ذات الخطوة الموحدة والتي كاتت إيجابية في الاوزان المنخفضة بزيادة الاوزان ظهرت سلبية نتائج الاستخلاص.

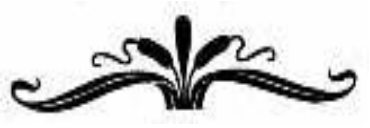

